\title{
Nitric Oxide Regulates Seedling Growth and Mitochondrial Responses in Aged Oat Seeds
}

\author{
Chunli Mao ${ }^{1,+}$, Yanqiao Zhu ${ }^{1,+}$, Hang Cheng ${ }^{1}$, Huifang Yan ${ }^{1}$, Liyuan Zhao ${ }^{1}$, Jia Tang ${ }^{1}$, \\ Xiqing Ma ${ }^{1,2}$ and Peisheng Mao ${ }^{1,2, *}$ \\ 1 College of Animal Science and Technology, China Agricultural University, Beijing 100193, China; \\ maochunlim@163.com (C.M.); yanq_zhu@cau.edu.cn (Y.Z.); chenghang0522@126.com (H.C.); \\ yanhui_fang@126.com (H.Y.);yuanlizhao1994@126.com (L.Z.); candytangjia@cau.edu.cn (J.T.); \\ ma2016@cau.edu.cn (X.M.) \\ 2 Key Laboratory of Pratacultural Science, Beijing Municipality, China Agricultural University, \\ No. 2 Yuanmingyuan West Road, Haidian District, Beijing 100193, China \\ * Correspondence: maopeisheng@hotmail.com; Tel.: +86-010-62733311 \\ + These authors contributed equally to this work.
}

Received: 10 February 2018; Accepted: 26 March 2018; Published: 2 April 2018

\begin{abstract}
Mitochondria are the source of reactive oxygen species (ROS) in plant cells and play a central role in the mitochondrial electron transport chain (ETC) and tricarboxylic acid cycle (TCA) cycles; however, ROS production and regulation for seed germination, seedling growth, as well as mitochondrial responses to abiotic stress, are not clear. This study was conducted to obtain basic information on seed germination, embryo mitochondrial antioxidant responses, and protein profile changes in artificial aging in oat seeds (Avena sativa L.) exposed to exogenous nitric oxide (NO) treatment. The results showed that the accumulation of $\mathrm{H}_{2} \mathrm{O}_{2}$ in mitochondria increased significantly in aged seeds. Artificial aging can lead to a loss of seed vigor, which was shown by a decline in seed germination and the extension of mean germination time (MGT). Seedling growth was also inhibited. Some enzymes, including catalase (CAT), glutathione reductase (GR), dehydroascorbate reductase (DHAR), and monodehydroascorbate reductase (MDHAR), maintained a lower level in the ascorbate-glutathione (AsA-GSH) scavenging system. Proteomic analysis revealed that the expression of some proteins related to the TCA cycle were down-regulated and several enzymes related to mitochondrial ETC were up-regulated. With the application of $0.05 \mathrm{mM} \mathrm{NO}$ in aged oat seeds, a protective effect was observed, demonstrated by an improvement in seed vigor and increased $\mathrm{H}_{2} \mathrm{O}_{2}$ scavenging ability in mitochondria. There were also higher activities of CAT, GR, MDHAR, and DHAR in the AsA-GSH scavenging system, enhanced TCA cycle-related enzymes (malate dehydrogenase, succinate-CoA ligase, fumarate hydratase), and activated alternative pathways, as the cytochrome pathway was inhibited. Therefore, our results indicated that seedling growth and seed germinability could retain a certain level in aged oat seeds, predominantly depending on the lower NO regulation of the TCA cycle and AsA-GSH. Thus, it could be concluded that the application of $0.05 \mathrm{mM}$ NO in aged oat seeds improved seed vigor by enhancing the mitochondrial TCA cycle and activating alternative pathways for improvement.
\end{abstract}

Keywords: nitric oxide; ROS; mitochondria; proteins; alternative pathway; antioxidant enzymes

\section{Introduction}

High-quality seeds are extremely important to agricultural production, productivity, and germplasm conservation. However, seed deterioration occurs during storage, even under optimal storage conditions, which causes the loss of seed vigor. Various biochemical and metabolic alterations 
take place during seed aging, including electrolyte leakage, the loss of cell membrane integrity, DNA alteration, and damage of mitochondrial structure and function [1-3]. Although the mechanisms of seed aging are still being researched, reactive oxygen species (ROS) are considered the main factor contributing to seed aging and leading to the damage of lipids, DNA, and proteins [4,5]. ROS, including hydrogen peroxide $\left(\mathrm{H}_{2} \mathrm{O}_{2}\right)$, hydroxyl radical $(\cdot \mathrm{OH})$, and superoxide radical $\left(\mathrm{O}_{2}{ }^{-}\right)$, accumulate in the aged seeds of sunflowers (Helianthus annuus L.) [6], oats [2], and elm (Ulmus pumila L.) [7]. Therefore, it is necessary to explore the aging mechanisms of the detrimental role of ROS in deteriorated seeds.

Mitochondrion can provide energy for cell metabolism and transport by respiration and is the main site for the generation and scavenging of ROS [8-10]. Plant mitochondria have two different pathways for electron transport at the ubiquinone pool, the cyanide-sensitive cytochrome pathway and the cyanide-resistant alternative pathway. The cytochrome pathway, consisting of complex I (NADH dehydrogenase), complex II (succinate dehydrogenase), complex III, and finally complex IV (cytochrome oxidase), catalyze the four-electron reduction of $\mathrm{O}_{2}$ to $\mathrm{H}_{2} \mathrm{O}$ [11]. However, complex I and complex III are considered as the main source of ROS [8,12]. There are two terminal oxidases in the plant mitochondrial electron transport chain (ETC). In addition to the cytochrome pathway, alternative oxidase (AOX) can be used as terminal oxidase to reduce $\mathrm{O}_{2}$ to $\mathrm{H}_{2} \mathrm{O}$ in the alternative respiratory pathway descried in plant mitochondria and could produce a branch in the ETC. Then, electrons in ubiquinone are divided between the cytochrome pathway (complex III and complex IV) and AOX $[11,13]$. It has been reported that severe drought stress induces the accumulation of ROS in wheat (Triticum aestivum $\mathrm{L}$.) seedlings; however, alternative pathways could improve drought-resistance by removing ROS [14]. Over-expression of the AOX gene reduces the level of ROS in Arabidopsis under chilling stress, while suppressing $A O X$ induces higher levels of ROS [15]. Thus, studies have shown that AOX could play important role in balancing ROS during plant oxidative stress. However, the relationship between the alternative pathway and ROS accumulation in the mitochondria of aged seeds has not yet been thoroughly studied.

Mitochondria are important sites for the scavenging of ROS, consisting of the enzymatic antioxidant systems and non-enzymatic antioxidant systems, such as superoxide dismutase (SOD), catalase (CAT), and ascorbate-glutathione (AsA-GSH) cycles [16-18]. It has been shown that the activities of antioxidant enzymes decrease as a result of seed aging [2,6]. However, there is no further information on the role of different antioxidant enzymes on ROS scavenging in mitochondria.

Nitric oxide (NO) is a gaseous signaling transduction molecule and plays an important role in responding to diverse stressors in plants. It has been suggested that $\mathrm{NO}$ is a regulator of germination as well as $\mathrm{H}_{2} \mathrm{O}_{2}[5,19]$. Some research has provided evidence that many of the crucial physiological processes of plants are related with $\mathrm{NO}$, including germination, respiration, stress response, and regulating ROS balance. Exogenous $\mathrm{NO}$ could significantly enhance the germination rate of wheat seeds and decreased the content of $\mathrm{H}_{2} \mathrm{O}_{2}$ and $\mathrm{O}_{2}{ }^{-}$in the mitochondria under salt stress [20]. NO treatment has been shown to improve the activities of CAT, SOD, and APX in cucumber (Cucumis sativus L.) under salt stress [21] and wheat seed under copper stress [22]. Moreover, NO could inhibit the cytochrome pathway, while inducing the alternative pathway [23]. Royo et al. [24] showed that NO is essential for the induction of the AOX pathway under phosphate-limiting conditions in Arabidopsis. However, there is little known about the role of NO in regulating mitochondrial ROS and antioxidant mechanisms in aged seeds.

Recently, proteomics has become an important method to study the mechanisms of aged seeds and detect changes in various cellular processes. Li et al. [7] identified 48 mitochondrial proteins that changed in abundance on aged elm seeds and found that the alteration of voltage-dependent anion channels (VDAC), tricarboxylic acid cycle (TCA), and mitochondrial ETC were related to seed aging. Yin et al. [25] revealed the mitochondrial metabolite of aged rice (Oryza sativa L.) seeds under the critical node and found that induction of the alternative pathway led to a decrease in cytochrome $\mathrm{c}$ and the accumulation of ROS. However, the way in which events are regulated in the mitochondria of aged seeds should be further studied. 
Oat, a low-carbon and eco-friendly crop, can be planted in regions experiencing a variety of environmental stresses, including infertility, salinity, drought, and cold. This study was designed to determine changes in mitochondria as a result of exogenously applied NO, including seedling growth, ROS accumulation, antioxidant enzyme improvement in the AsA-GSH cycle, and proteomics information in the embryo of oat seeds after aging, and to understand the response of mitochondria to seed deterioration.

\section{Results}

\subsection{Changes in Seed Germination and Seedling Growth in Aged Oat Seeds under Nitric Oxide Treatments}

The germination percentage and seedling length of aged oat seeds (A0) was significantly $(p<0.05)$ lower than non-aged seeds (CK), and improved significantly $(p<0.05)$ after NO treatment $(\mathrm{A} 1)$ in all areas except for seed germination (Table 1). On the other hand, there were severe inhibiting roles of higher NO contents (A3 and A4, Figure 1) on root and shoot length. Mean germination time (MGT) of aged oat seeds $(\mathrm{A} 0)$ was significantly higher $(p<0.05)$ than CK and could also be significantly $(p<0.05)$ reduced with NO treatment (A1). However, there were no effect of higher NO content (A2 and A3) on MGT (Table 1).

Table 1. The germination percentage, mean germination time, and seedling length of aged oat seeds with different $\mathrm{NO}$ concentrations. Data are means \pm standard deviation (SD) from four replications for each treatment. Different letters indicate significant differences among NO treatments $(p<0.05)$.

\begin{tabular}{ccccc}
\hline Treatment & $\begin{array}{c}\text { Germination } \\
\text { Percentage (\%) }\end{array}$ & $\begin{array}{c}\text { Mean Germination } \\
\text { Time (d) }\end{array}$ & Root Length (cm) & Shoot Length (cm) \\
\hline CK & $99 \pm 1.2^{\mathrm{a}}$ & $1.9 \pm 0.04^{\mathrm{d}}$ & $6.2 \pm 0.30^{\mathrm{a}}$ & $4.7 \pm 0.38^{\mathrm{a}}$ \\
A0 & $68 \pm 5.9^{\mathrm{b}, \mathrm{c}}$ & $3.4 \pm 0.14^{\mathrm{b}}$ & $3.9 \pm 0.50^{\mathrm{c}}$ & $1.9 \pm 0.23^{\mathrm{c}}$ \\
A1 & $78 \pm 4.3^{\mathrm{b}}$ & $3.0 \pm 0.04^{\mathrm{c}}$ & $5.1 \pm 0.54^{\mathrm{b}}$ & $2.4 \pm 0.46^{\mathrm{b}}$ \\
A2 & $75 \pm 8.3^{\mathrm{b}, \mathrm{c}}$ & $3.3 \pm 0.20^{\mathrm{b}}$ & $4.1 \pm 0.40^{\mathrm{c}}$ & $2.0^{\mathrm{b}} \pm 0.27^{\mathrm{b}, \mathrm{c}}$ \\
A3 & $70 \pm 8.2^{\mathrm{b}, \mathrm{c}}$ & $3.4 \pm 0.29^{\mathrm{b}}$ & $2.0 \pm 0.39^{\mathrm{d}}$ & $0.7 \pm 0.08^{\mathrm{d}}$ \\
A4 & $65 \pm 6.2^{\mathrm{c}}$ & $3.9 \pm 0.19^{\mathrm{a}}$ & $1.7 \pm 0.05^{\mathrm{d}}$ & $0.6 \pm 0.08^{\mathrm{d}}$ \\
\hline
\end{tabular}

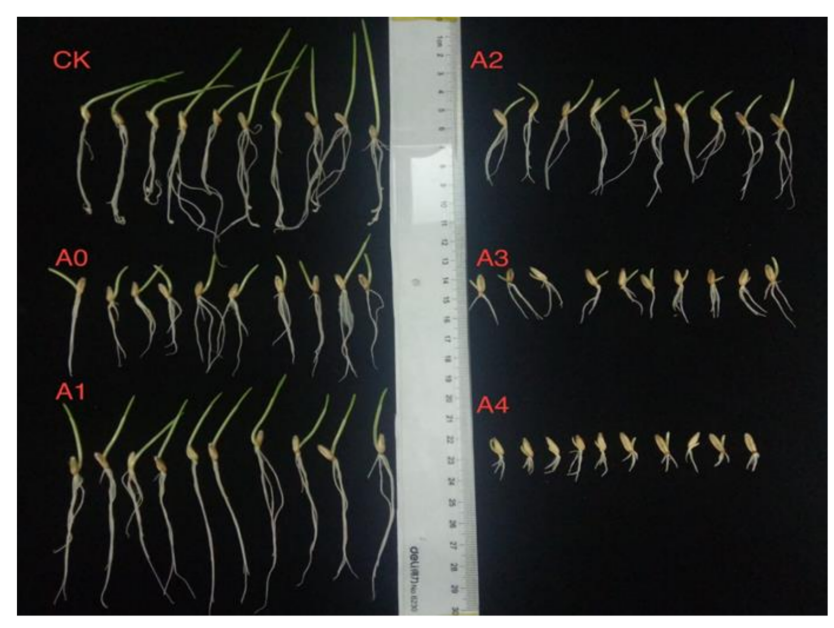

Figure 1. Patterns of seedling length in aged oat seeds with different NO treatments.

\subsection{Changes in Mitochondrial $\mathrm{H}_{2} \mathrm{O}_{2}$ Content, Malate Dehydrogenase (NAD-MDH), and $\mathrm{O}_{2}^{-}$Content in} Aged Oat Seeds under NO Treatments

The content of mitochondrial $\mathrm{H}_{2} \mathrm{O}_{2}$ in aged seeds (A0) was significantly higher $(p<0.05)$ compared to $\mathrm{CK}$, and NO application significantly $(p<0.05)$ decreased the content of $\mathrm{H}_{2} \mathrm{O}_{2}$ in aged seeds 
(Figure 2A). However, there were no significant differences $(p>0.05)$ in $\mathrm{H}_{2} \mathrm{O}_{2}$ content among the treatments of $\mathrm{A} 1, \mathrm{~A} 2$, and $\mathrm{A} 3$, and $\mathrm{H}_{2} \mathrm{O}_{2}$ content reached the lowest point at $\mathrm{A} 4$.

There was no significant difference $(p>0.05)$ in terms of the activity of mitochondrial NAD-MDH between $\mathrm{A} 0$ and $\mathrm{CK}$, but activities of NAD-MDH were significantly improved $(p<0.05)$ with lower level exogenous NO treatments (A1 and A2), compared to A0 (Figure 2B). Furthermore, activity decreased significantly $(p<0.05)$ as NO content increased from A1 to A4 and reached the lowest level at A3. There was no significant difference $(p>0.05)$ between $\mathrm{A} 3$ and $\mathrm{A} 4$, which were similar to A0 (Figure 2B).

The mitochondrial $\mathrm{O}_{2}{ }^{-}$content in aged seeds (A0) increased compared to $\mathrm{CK}$, and $\mathrm{NO}$ application decreased the content of $\mathrm{O}_{2}{ }^{-}$in aged seeds (Figure 2C). However, there were no significant differences $(p>0.05)$ of $\mathrm{O}_{2}^{-}$content among the treatments of $\mathrm{CK}, \mathrm{A} 0, \mathrm{~A} 1, \mathrm{~A} 2, \mathrm{~A} 3$, and $\mathrm{A} 4$.
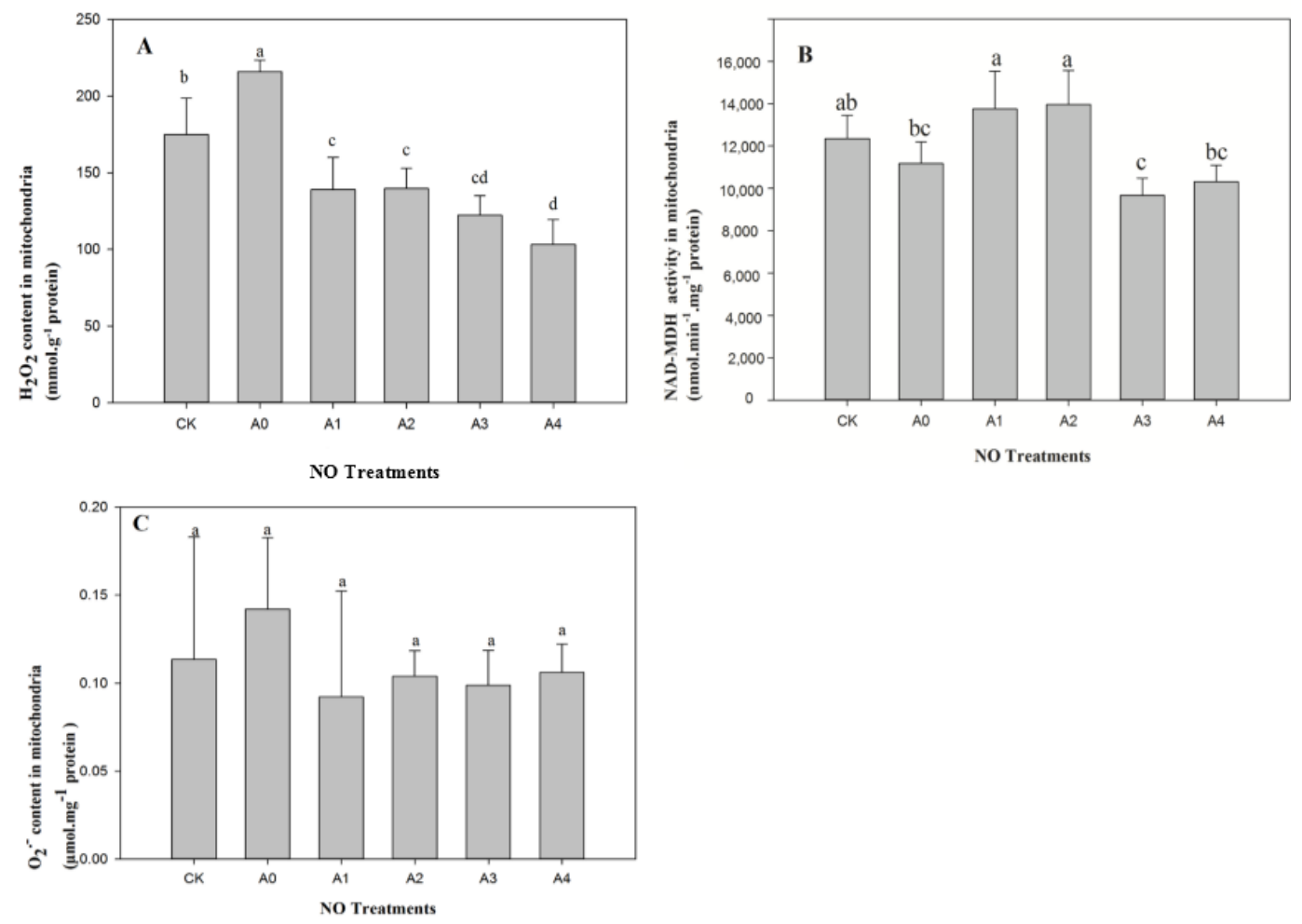

Figure 2. Changes in mitochondrial $\mathrm{H}_{2} \mathrm{O}_{2}$ content and NAD-MDH activity in aged oat seeds with different $\mathrm{NO}$ treatments. (A) $\mathrm{H}_{2} \mathrm{O}_{2}$ content; (B) NAD-MDH activities; (C) $\mathrm{O}_{2}{ }^{-}$content. Data are means $\pm \mathrm{SD}$ from three replications for each treatment. Different letters indicate significant differences among NO treatments $(p<0.05)$.

\subsection{Changes in Mitochondrial Antioxidant Enzymes in Aged Oat Seeds under Nitric Oxide Treatments}

There was a significant difference $(p<0.05)$ in the activity of mitochondrial glutathione reductase (GR) between $\mathrm{A} 0$ and $\mathrm{CK}$, but no differences were found in terms of CAT, monodehydroascorbate reductase (MDHAR), and dehydroascorbate reductase (DHAR) (Figure 3). Furthermore, activities of GR, CAT, MDHAR, and DHAR were all significantly improved $(p<0.05)$ with lower level of exogenous NO treatment (A1), compared to A0. However, enzyme activities displayed different tendencies as NO application increased from A1 to A4. The activities of GR, MDHAR, and DHAR presented no significant increase among NO treatments from A1 to A4 (Figure 3A,C,D). For CAT, activity decreased significantly $(p<0.05)$ with increasing exogenous $\mathrm{NO}$ content and reached the lowest level at A4 treatment, which showed no significant difference to $\mathrm{CK}$ or A0 (Figure 3B). 

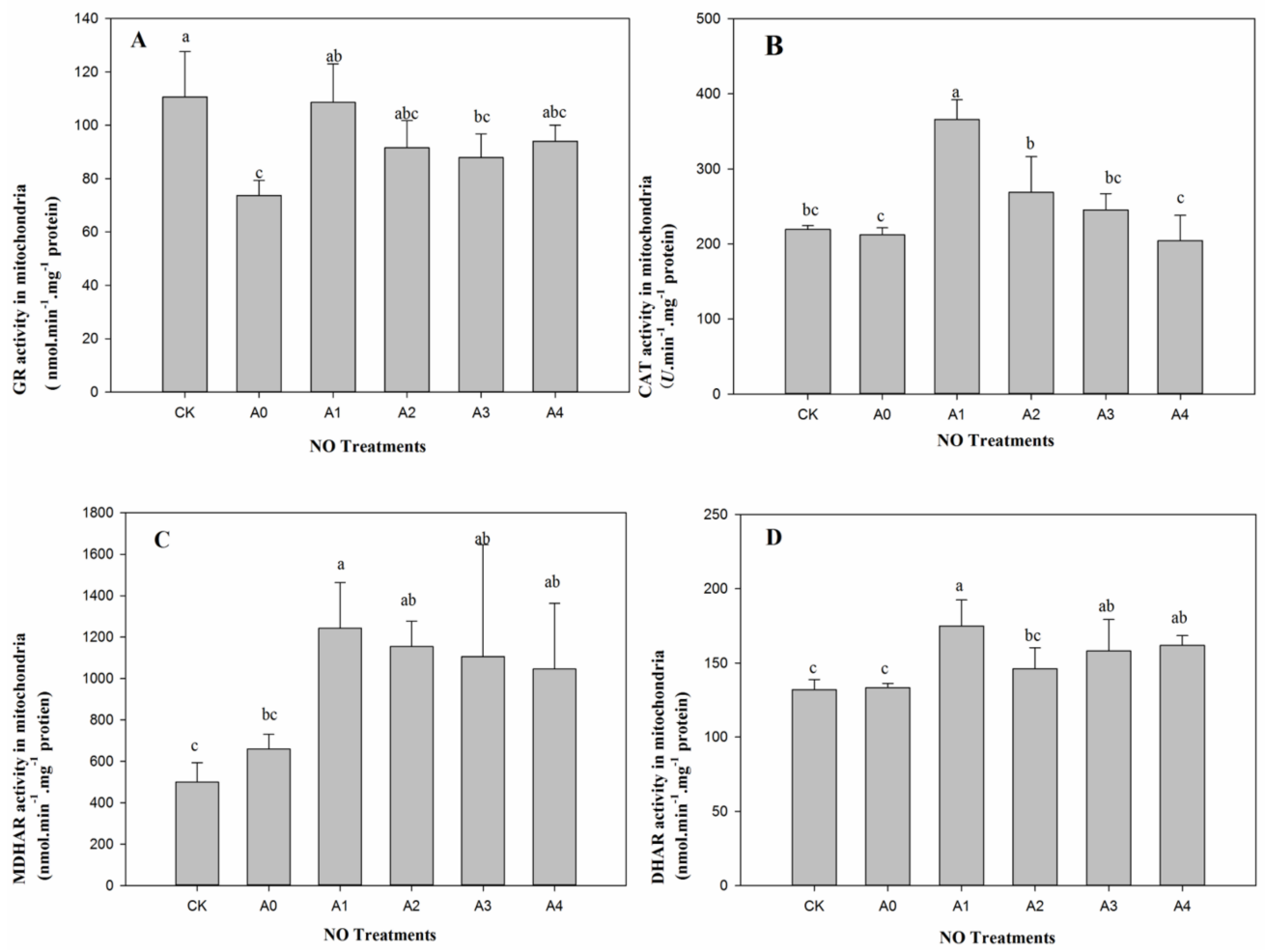

Figure 3. Changes in mitochondrial antioxidant enzyme activities in aged oat seeds with different NO treatments. (A) Glutathione reductase (GR) activities; (B) Catalase (CAT) activities; (C) Monodehydroascorbate reductase (MDHAR) activities; (D) Dehydroascorbate reductase (DHAR) activities. Data are means \pm SD from three replications for each treatment Different letters indicate significant differences among NO treatments $(p<0.05)$.

\subsection{Changes in Mitochondrial Complex IV in Aged Oat Seeds under Nitric Oxide Treatments}

The activity of mitochondrial complex IV in aged oat seeds (A0) decreased significantly $(p<0.05)$ compared to un-aged seeds (CK). There were different effects for different NO contents on the activity of mitochondrial complex IV in aged seeds. The activity of mitochondrial complex IV in the aged seeds significant decreased $(p<0.05)$ at the lower NO treatment level (A1), then activity began to increase with NO treatments from A2 to A4. The level of activity of mitochondrial complex IV under A3 and A4 treatments attained the highest level and returned to a similar level to CK (Figure 4).

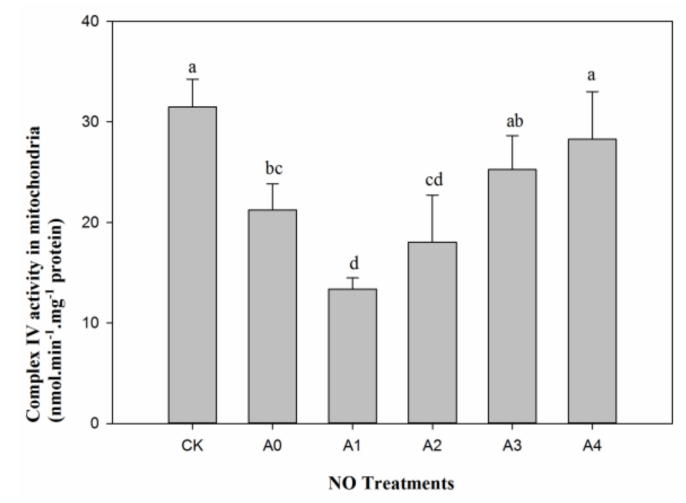

Figure 4. Changes in mitochondrial complex IV activity in aged oat seeds with different NO treatments. Data are means \pm SD from three replications for each treatment. Different letters indicate significant differences among NO treatments $(p<0.05)$. 


\subsection{Changes in Mitochondrial Proteins in Aged Oat Seeds under Nitric Oxide Treatments}

According to the results of $\mathrm{H}_{2} \mathrm{O}_{2}$ and antioxidant enzymes in aged oat seeds treated with $\mathrm{NO}$, we found that $\mathrm{A} 1$ treatment was the most sensitive in terms of mitochondrial physiology. Therefore, seed samples from $\mathrm{CK}, \mathrm{A} 0$, and $\mathrm{A} 1$ were selected for the proteomics analysis.

A total of 3874 proteins were found in the quantitative analysis of proteomics. Of the proteins screened with mitochondrion markers, 103 mitochondrial related proteins were identified. At the same time, the results of Gene Ontology (GO) annotation showed that 37 proteins were enriched in mitochondrial related pathways, and there were four overlapping proteins found between mitochondrial markers and GO annotation. Therefore, a total of 136 mitochondrial proteins could be identified. In order to screen the differentially expressed proteins depending on the fold changes, we divided the results of the proteomic analysis into three comparison groups, including A1/A0 (0.05 mM sodium nitroprusside (SNP) treatment compared to $0 \mathrm{mM} \mathrm{SNP}$ in aged seeds), A0/CK (aged seeds compared to unaged seeds), and A1/CK (0.05 mM sodium nitroprusside treatment in aged seeds compared to unaged seeds).

In general, only 52 differentially expressed proteins were determined for their name and functions according to the MapMan (Table 2). For A1/A0, 11 differentially expressed proteins were identified, including eight up-regulated and three down-regulated proteins. There were 11 up-regulated proteins and 29 down-regulated proteins in $\mathrm{A} 0 / \mathrm{CK}$, and 11 up-regulated and 24 down-regulated proteins in $\mathrm{A} 1 / \mathrm{CK}$. The number of up-regulated proteins was very similar, and there were much more down-regulated proteins in the group of $\mathrm{A} 0 / \mathrm{CK}$ and $\mathrm{A} 1 / \mathrm{CK}$. It could be found that the number of up-regulated proteins were much more than that of down-regulated proteins in aged seeds with NO treatment (A1/A0). However, there were much more down-regulated proteins than up-regulated proteins with aging treatments in groups of A0/CK and A1/CK. According to the MapMan analysis, these differentially expressed proteins were classified into 12 functional categories, including TCA cycle, mitochondrial ETC, protein synthesis and elongation, signaling, RNA transcription, heat stress, cell division, and transport metabolism. Among these proteins, large numbers of differentially expressed proteins belonged to the functional categories of the TCA cycle and protein synthesis and elongation, which, as a proportion of total proteins, attained the highest level of $19.23 \%$. The mitochondrial ETC followed this, at $15.38 \%$ (Figure 5).

Furthermore, from the overview of a hierarchical clustering analysis of the differentially expressed proteins in the three comparison groups, the differentially expressed proteins of $\mathrm{A} 1 / \mathrm{A} 0, \mathrm{~A} 0 / \mathrm{CK}$, and A1/CK showed different expression patterns (Figure 6A). Although there were three differentially expressed proteins identified in all three groups, two proteins existed in the groups of $\mathrm{A} 1 / \mathrm{A} 0$ and $\mathrm{A} 1 / \mathrm{CK}$, the same 21 proteins in $\mathrm{A} 1 / \mathrm{CK}$ and $\mathrm{A} 0 / \mathrm{CK}$, and the same five proteins were found in $\mathrm{A} 1 / \mathrm{A} 0$ and $\mathrm{A} 0 / \mathrm{CK}$. Then, the remaining one, nine and 11 differentially expressed proteins only existed in the $\mathrm{A} 1 / \mathrm{A} 0, \mathrm{~A} 1 / \mathrm{CK}$, and $\mathrm{A} 0 / \mathrm{CK}$ groups, respectively (Figure $6 \mathrm{~B}$ ). In particular, this occurred during the physiological processes, including the mitochondrial TCA cycle, ETC, and protein synthesis and elongation. Some proteins located in the TCA cycle were down-regulated in the aged seeds (A0/CK), such as the subunit of Succinate-CoA ligase (I1LYN0, K3ZV34, B4FRH5 and W5C4B7), fumarate hydratase (R4X771), malic enzyme (K3ZRI5), aldehyde dehydrogenase (K3YRJ0), and a subunit of Succinate-CoA dehydrogenase (M3AS20). However, the proteins of the subunit of Succinate-CoA ligase (I1LYN0 and K3ZV34) were only up-regulated in the aged seeds with NO treatment (A1/A0). Particularly for the Fumarate hydratase 1(Q10LR5), up-regulation appeared in seeds with NO treatment (A1/A0 and A1/CK). For the mitochondrial ETC proteins, the subunit of ATP synthase (W5BEP1 and A0A0K9R2N3) and external alternative NAD(P)H-ubiquinone oxidoreductase (Q9SKT7) were both up-regulated in the aged seeds $(\mathrm{A} 0 / \mathrm{CK})$ and with $\mathrm{NO}$ treatment $(\mathrm{A} 1 / \mathrm{CK})$; while, the subunit of ATP synthase (A0A200QHI3) was down-regulated in the aged seeds with NO application (A1/A0). For protein synthesis and elongation, aging treatment (A0/CK) could lead the proteins to become down-regulated, for example, the factor of elongation (A0A0D3H000, F2DG12, and F2EDF6), lon protease homolog (A0A0D3GV84 and W5C618); however, the factor of elongation (A0A0D3H000 
and F2DG12) would be up-regulation with $\mathrm{NO}$ treatment (A1/A0). In the group of A1/CK, most proteins related to protein synthesis and elongation were down-regulated, except for the Chaperon in CPN60-like (Q8L7B5). Therefore, the proteins of the mitochondrial TCA cycle, mitochondrial ETC, and protein synthesis and elongation had different patterns across different groups (A1/A0, A0/CK, and $\mathrm{A} 1 / \mathrm{CK})$.
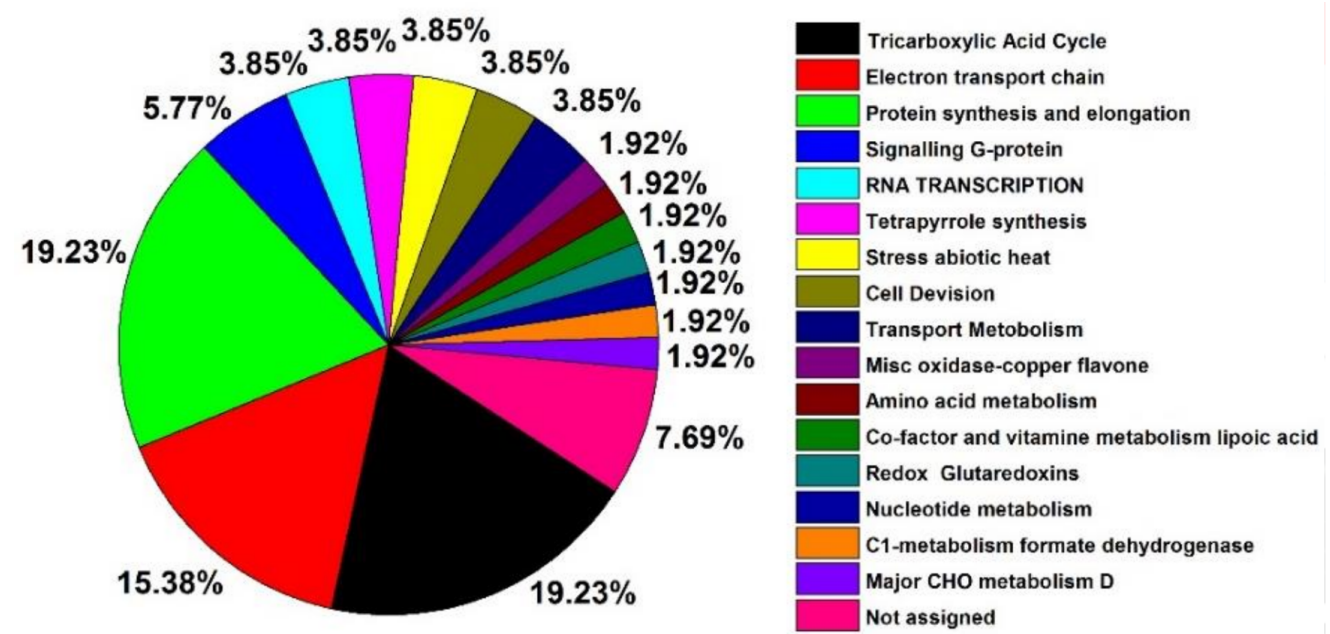

Figure 5. The functional category distribution of the 52 differently expressed mitochondrial proteins in aged oat seeds. Note: Functional classification was based on the MapMan.
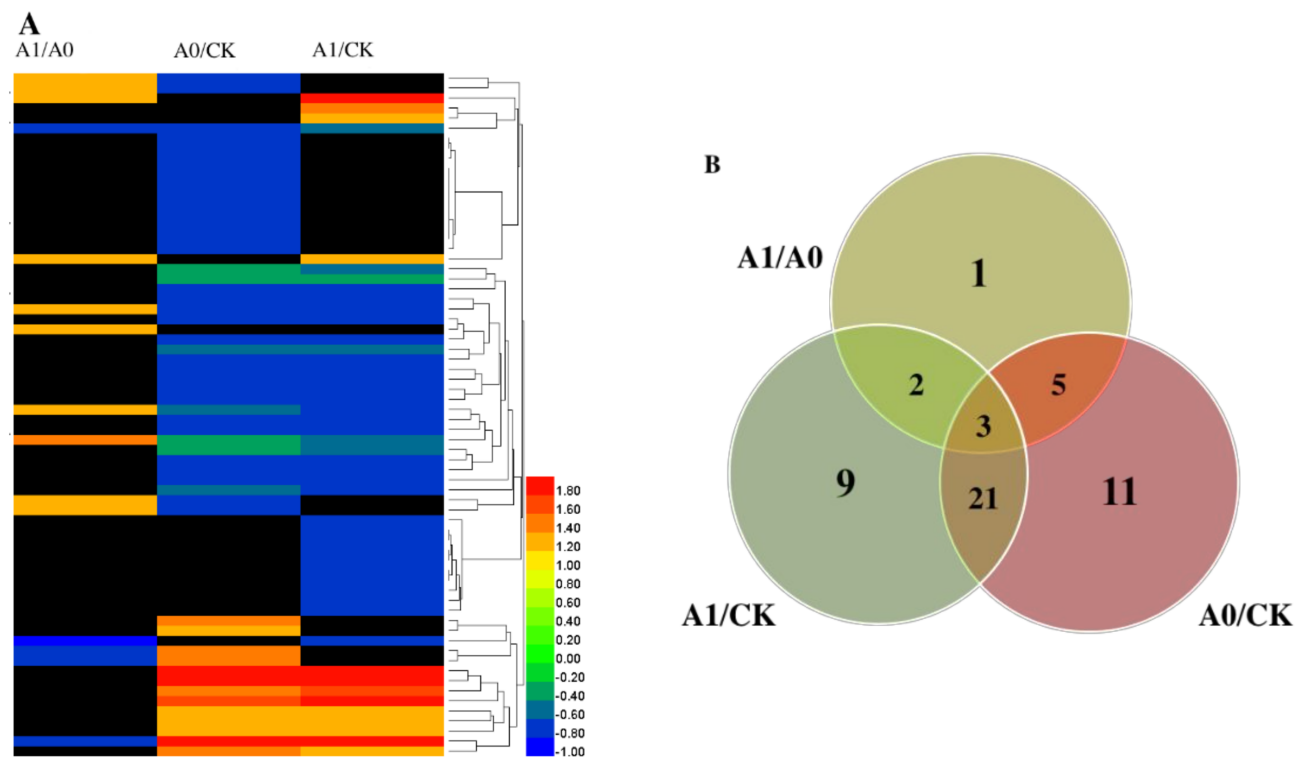

Figure 6. (A) Clustering analysis of differentially expressed proteins and (B) The number of differentially expressed proteins as a result of the exogenous application of NO across different groups (A1/A0, A0/CK, A1/CK) of aged oat seeds. Note: The color scale bar in the right of the hierarchical clustering analysis indicates the up-regulated (ratio $>0.00$ ) and the down-regulated (ratio $<0.00)$ proteins. In the Venn diagram, the overlapping regions of cycles indicate proteins that were regulated in both or all treatments, whereas non-overlapping circles indicate proteins regulated in the only treatment. 
Table 2. Total of 52 differentially expressed proteins across three comparison groups in aged oat seeds in response to exogenous NO treatment.

\begin{tabular}{|c|c|c|c|c|c|}
\hline \multirow[t]{2}{*}{ Hit Number } & \multirow[t]{2}{*}{ Accession No. } & \multirow[t]{2}{*}{ Protein Name (Species) } & \multicolumn{3}{|c|}{ Fold Change } \\
\hline & & & A1/A0 & A0/CK & A1/CK \\
\hline \multicolumn{6}{|c|}{ TCA cycle } \\
\hline I1LYN0 & AT2G20420 & $\begin{array}{l}\text { Succinate-CoA ligase [ADP-forming] subunit beta, mitochondrial } \\
\text { Glycine max }\end{array}$ & 1.25 & 0.67 & ns \\
\hline K3ZV34 & AT5G23250 & $\begin{array}{l}\text { Succinate-CoA ligase [ADP-forming] subunit alpha, mitochondrial } \\
\text { Setaria italica }\end{array}$ & 1.33 & 0.76 & ns \\
\hline Q10LR5 & AT5G50950 & $\begin{array}{l}\text { Fumarate hydratase 1, mitochondrial, putative, expressed } \\
\text { Oryza sativa subsp. japonica }\end{array}$ & 1.25 & ns & 2.56 \\
\hline R4X771 & AT5G50950 & Fumarate hydratase, mitochondrial Taphrina deformans & ns & 0.40 & 0.49 \\
\hline K3ZRI5 & AT2G13560 & Malic enzyme Setaria italica & $\mathrm{ns}$ & 0.70 & 0.71 \\
\hline K3YRJ0 & AT1G79440 & Aldehyde dehydrogenase Setaria italica & ns & 0.77 & 0.73 \\
\hline B4FRH5 & AT2G20420 & $\begin{array}{l}\text { Succinate-CoA ligase [ADP-forming] subunit beta, mitochondrial } \\
\text { Zea mays }\end{array}$ & ns & 0.79 & ns \\
\hline W5C4B7 & AT5G23250 & $\begin{array}{c}\text { Succinate-CoA ligase [ADP-forming] subunit alpha, mitochondrial } \\
\text { Triticum aestivum }\end{array}$ & ns & 0.67 & ns \\
\hline V4KMJ1 & AT5G66760 & $\begin{array}{l}\text { Succinate dehydrogenase [ubiquinone] flavoprotein subunit, } \\
\text { mitochondrial Eutrema salsugineum }\end{array}$ & ns & 1.52 & ns \\
\hline M3AS20 & AT5G40650 & $\begin{array}{l}\text { Succinate dehydrogenase [ubiquinone] iron-sulfur subunit, } \\
\text { mitochondrial Pseudocercosporafijiensis }\end{array}$ & ns & 0.74 & ns \\
\hline \multicolumn{6}{|c|}{ Mitochondrial electron transport } \\
\hline A0A200QHI3 & AT3G52300 & ATP synthase subunit d, mitochondrial Macleaya cordata & 0.80 & ns & 0.67 \\
\hline W5BEP1 & AT3G52300 & ATP synthase subunit d, mitochondrial Triticum aestivum & ns & 2.20 & 2.37 \\
\hline A0A0K9R2N3 & AT3G52300 & ATP synthase subunit d, mitochondrial Spinacia oleracea & ns & 1.24 & ns \\
\hline V4LNR7 & AT3G52300 & ATP synthase subunit d, mitochondrial Eutrema salsugineum & ns & ns & 0.70 \\
\hline A0A1J3KAQ0 & AT5G08530 & $\begin{array}{l}\text { NADH dehydrogenase [ubiquinone] flavoprotein 1, mitochondrial } \\
\text { Noccaea caerulescens }\end{array}$ & ns & 0.72 & 0.72 \\
\hline W5I0L9 & AT3G03070 & $\begin{array}{l}\text { NADH dehydrogenase [ubiquinone] iron-sulfur protein 6, } \\
\text { mitochondrial Triticum aestivum }\end{array}$ & ns & ns & 0.68 \\
\hline Q9SKT7 & AT5G13430 & $\begin{array}{l}\text { External alternative } \mathrm{NAD}(\mathrm{P}) \mathrm{H} \text {-ubiquinone oxidoreductase } \mathrm{B} 4 \\
\text { mitochondrial Arabidopsis thaliana }\end{array}$ & ns & 3.93 & 4.23 \\
\hline K3Y9D3 & AT5G13430 & $\begin{array}{l}\text { Cytochrome b-c1 complex subunit Rieske, mitochondrial } \\
\text { Setaria italica }\end{array}$ & ns & ns & 0.78 \\
\hline \multicolumn{6}{|c|}{ Protein synthesis and elongation } \\
\hline A0A0D3H000 & AT4G11120 & Elongation factor Ts, mitochondrial Oryza barthii & 1.35 & 0.65 & ns \\
\hline B6T7S2 & AT5G47320 & 40S ribosomal protein S19 mitochondrial Zea mays & ns & 0.59 & 0.58 \\
\hline F2DG12 & AT2G45030 & Elongation factor G, mitochondrial Hordeum vulgare subsp. vulgare & 1.33 & 0.46 & 0.66 \\
\hline Q5JNL6 & AT1G51980 & Mitochondrial processing peptidase Oryza sativa subsp. japonica & ns & ns & 0.68 \\
\hline B6U5I0 & AT2G29530 & $\begin{array}{l}\text { Mitochondrial import inner membrane translocase subunit Tim10 } \\
\text { Zea mays }\end{array}$ & ns & 0.72 & 0.62 \\
\hline Q6EN45 & AT5G53140 & $\begin{array}{c}\text { Probable protein phosphatase } 2 \mathrm{C} \text { member } 13 \text {, mitochondrial } \\
\text { Oryza sativa subsp. japonica }\end{array}$ & ns & 0.42 & 0.62 \\
\hline A0A0D3GV84 & AT5G26860 & Lon protease homolog, mitochondrial Oryza barthii & $\mathrm{ns}$ & 0.66 & 0.75 \\
\hline Q8L7B5 & AT2G33210 & Chaperonin CPN60-like 1, mitochondrial Arabidopsis thaliana & ns & ns & 1.49 \\
\hline F2EDF6 & AT4G11120 & Elongation factor Ts, mitochondrial Hordeum vulgare subsp. vulgare & ns & 0.74 & ns \\
\hline W5C618 & AT5G26860 & Lon protease homolog, mitochondrial Triticum aestivum & ns & 0.76 & ns \\
\hline \multicolumn{6}{|c|}{ Signalling, G-protein } \\
\hline F2CSX0 & AT5G27540 & Mitochondrial Rho GTPase Hordeum vulgare subsp. vulgare & $\mathrm{ns}$ & ns & 0.75 \\
\hline A0A1Q3B5G5 & AT5G27540 & Mitochondrial Rho GTPase Cephalotus follicularis & ns & 0.40 & 0.42 \\
\hline F2E3Y6 & AT5G39900 & $\begin{array}{c}\text { Translation factor GUF1 homolog, mitochondrial Hordeum vulgare } \\
\text { subsp. vulgare }\end{array}$ & ns & 0.76 & ns \\
\hline
\end{tabular}


Table 2. Cont.

\begin{tabular}{|c|c|c|c|c|c|}
\hline \multirow[t]{2}{*}{ Hit Number } & \multirow[t]{2}{*}{ Accession No. } & \multirow[t]{2}{*}{ Protein Name (Species) } & \multicolumn{3}{|c|}{ Fold Change } \\
\hline & & & A1/A0 & A0/CK & A1/CK \\
\hline \multicolumn{6}{|c|}{ RNA transcription } \\
\hline Q7X745-2 & AT5G39840 & $\begin{array}{c}\text { Isoform } 2 \text { of ATP-dependent RNA helicase SUV3L, mitochondrial } \\
\text { Oryza sativa subsp. japonica }\end{array}$ & 1.33 & 0.62 & ns \\
\hline Q6K7E2 & AT2G44020 & $\begin{array}{l}\text { Mitochondrial transcription termination factor-like Oryza sativa } \\
\text { subsp. japonica }\end{array}$ & ns & 0.73 & ns \\
\hline \multicolumn{6}{|c|}{ Tetrapyrrole synthesis, protoporphyrin IX oxidase } \\
\hline W5GSR7 & AT1G48520 & $\begin{array}{l}\text { Glutamyl-tRNA(Gln) amidotransferase subunit B, } \\
\text { chloroplastic/mitochondrial Triticum aestivum }\end{array}$ & ns & 0.77 & 0.77 \\
\hline K3Y6C6 & AT5G14220 & Protoporphyrinogen oxidase Setaria italica & 0.75 & 2.43 & 1.83 \\
\hline \multicolumn{6}{|c|}{ Stress, abiotic, heat } \\
\hline G2X6B5 & AT5G22060 & Mitochondrial protein import protein MAS5 Verticillium dahliae & ns & 1.56 & 1.66 \\
\hline A0A1J3J8H0 & AT5G22060 & $\begin{array}{l}\text { Heat shock } 70 \text { kDa protein 10, mitochondrial (Fragment) } \\
\text { Noccaea caerulescens }\end{array}$ & ns & 0.23 & 0.28 \\
\hline \multicolumn{6}{|c|}{ Cell devision } \\
\hline F2DZF0 & AT3G57090 & Mitochondrial fission 1 protein Hordeum vulgare subsp. vulgare & ns & 1.30 & 1.25 \\
\hline W4ZR59 & AT3G57090 & Mitochondrial fission 1 protein Triticum aestivum & ns & 0.73 & 0.68 \\
\hline \multicolumn{6}{|c|}{ Transport metobolism } \\
\hline Q5NAJ0 & AT1G14560 & $\begin{array}{l}\text { Graves disease mitochondrial solute carrier protein-like Oryza } \\
\text { sativa subsp. japonica }\end{array}$ & ns & 1.30 & 1.25 \\
\hline Q10QM8 & AT5G64970 & Mitochondrial carrier protein, expressed Oryza sativa subsp. japonica & ns & ns & 0.68 \\
\hline \multicolumn{6}{|c|}{ Misc, oxidase-copper, flavone } \\
\hline B4G146 & AT5G06580 & D-lactate dehydrogenase [cytochrome] mitochondrial Zea mays & 0.69 & 1.58 & ns \\
\hline \multicolumn{6}{|c|}{ Amino acid metabolism } \\
\hline B6SWZ4 & AT4G34030 & $\begin{array}{l}\text { Methylcrotonoyl-CoA carboxylase beta chain mitochondrial } \\
\text { Zea mays }\end{array}$ & ns & ns & 1.21 \\
\hline \multicolumn{6}{|c|}{ Co-factor and vitamine metabolism, lipoic acid } \\
\hline U5H066 & AT5G08415 & Lipoyl synthase, mitochondrial Microbotryum lychnidis-dioicae & ns & 0.73 & 0.72 \\
\hline \multicolumn{6}{|c|}{ Redox, Glutaredoxins } \\
\hline Q0JQ97 & AT3G15660 & $\begin{array}{l}\text { Monothiol glutaredoxin-S1, mitochondrial Oryza sativa } \\
\text { subsp. japonica }\end{array}$ & ns & 0.78 & ns \\
\hline \multicolumn{6}{|c|}{ Nucleotide metabolism } \\
\hline K3ZE81 & AT5G23300 & $\begin{array}{l}\text { Dihydroorotate dehydrogenase (quinone), mitochondrial } \\
\text { Setaria italica }\end{array}$ & ns & ns & 0.75 \\
\hline \multicolumn{6}{|c|}{ C1-metabolism formate dehydrogenase } \\
\hline A0A0D3GGT7 & AT5G14780 & Formate dehydrogenase, mitochondrial Oryza barthii & $\mathrm{ns}$ & 0.72 & 0.67 \\
\hline \multicolumn{6}{|c|}{ Major CHO metabolism, Degradation, sucrose, Invertases, nautral } \\
\hline Q10MC0 & AT1G56560 & $\begin{array}{c}\text { Neutral/alkaline invertase 1, mitochondrial Oryza sativa } \\
\text { subsp. japonica }\end{array}$ & ns & 0.76 & ns \\
\hline \multicolumn{6}{|c|}{ Not assigned } \\
\hline W5BQ98 & AT4G22310 & Mitochondrial pyruvate carrier Triticum aestivum & 1.31 & ns & ns \\
\hline Q6ZGV8 & AT3G52140 & $\begin{array}{c}\text { Clustered mitochondria protein homolog Oryza sativa } \\
\text { subsp. japonica }\end{array}$ & ns & 1.68 & 1.91 \\
\hline Q0JDA2 & AT1G47420 & $\begin{array}{c}\text { Succinate dehydrogenase subunit } 5 \text {, mitochondrial Oryza sativa } \\
\text { subsp. japonica }\end{array}$ & ns & 1.32 & 1.23 \\
\hline B6SPH3 & AT5G08040 & Mitochondrial import receptor subunit TOM5-like protein Zea mays & 1.45 & 0.33 & 0.45 \\
\hline
\end{tabular}

\section{Discussion}

Seed aging and deterioration during storage could induce the loss of seed vigor, and seed germination, especially MGT, is usually used to reflect the level of seed vigor. It has been reported that seed germination decreases in aged seeds, such as maize [26], oat [2], and elm [7]. In our study, 
seed germination percentage decreased significantly after 26 days of aging (Table 1). Exogenous NO promotes the germination of seeds under stress or no-stress conditions [27]. For example, NO has been shown to stimulate seed germination under severe salt stress in wheat [20], and NO pretreatment significantly improves seed germination under copper stress, also in wheat [21]. Accordingly, a lower level of NO treatment (i.e., group A1) could improve the seed germination percentage in aged oat seeds. However, the differences among A1, A2, and A3 were not significant, which meant that the improvement in seed germination was sensitive to lower contents of NO. Excessive content or no NO could depress seed germination. MGT, an important index of seed vigor, exhibited a strong vigor with a shorter time [28]. Meanwhile, MGT was dramatically shorter for the A1 compared to other treatments in the aged oat seeds, and the roots and seedlings were significantly elongated. The changes in MGT and seedling length illustrate that the aged oat seed reached a higher level of vigor with the application of $0.05 \mathrm{mM}$ NO. Aging leads to a change in MGT during germination. It has been shown that the transcripts encoding the proteins are associated with protein synthesis and impart changes during germination [29]. Based on the influence of imbibing time on protein abundance, different imbibing time was selected for uniform size aged seeds and non-aged seeds to ensure that they were at the same physiological point.

Mitochondrion is important organelle for respiration and metabolism, including mitochondrial ETC, and the TCA cycle. The ETC, composed of a series of electron carriers on the inner membrane of the mitochondrion, is called a respiratory chain. Furthermore, the mitochondrial ETC is a main site for ROS production, especially complex I and complex III [8,12]. It was found that the content of $\mathrm{H}_{2} \mathrm{O}_{2}$ significantly increased in aged seeds, but $\mathrm{O}_{2}{ }^{-}$content did not differ significantly, most likely because of the speed at which it was produced was not conductive to monitoring. Mitochondrial respiration might be disturbed and cause the over accumulation of ROS during seed storage. In this study, we found the mitochondrial NADH dehydrogenase [ubiquinone] flavoprotein 1 (A0A1J3KAQ0) in aged oat seeds (A0 and A1) was significantly lower than that in unaged seeds (CK). As a subunit of the mitochondrial membrane, respiratory chain NADH dehydrogenase (complex I), NADH dehydrogenase flavoprotein 1 (A0A1J3KAQ0), is believed to belong to the minimal assembly required for catalysis and complex I functions in the electron transfer from NADH to respiratory chain. The activity reduction of complex I limits the transmission of the mitochondrial respiratory chain. Jardim-Messeder et al. [30] illustrated that succinate dehydrogenase was an important site of ROS production in plant mitochondria, in addition to complex I and complex III, for enhancing $\mathrm{H}_{2} \mathrm{O}_{2}$ release, and could also be a limiting factor in plant growth through mitochondrial ROS generation. Li et al. [7] reported that the succinate dehydrogenase [ubiquinone] flavoprotein subunit 1 in mitochondrial ETC decreased in aged elm seeds. Furthermore, complex IV (Cytochrome c oxidase) was significantly lower in aged oat seeds compared to CK (Figure 5). Also, it was shown that NO could inhibit complex IV [31,32]. In our results, the activity of complex IV was significantly reduced only with a lower content of exogenous NO (A1), which reflected that the cytochrome respiratory chain was inhibited. ATP synthase (complex V) is responsible for ATP production in mitochondria. Different responses were found in terms of ATP synthase in oat seeds; the subunits of ATP synthase (W5BEP1 and A0A0K9R2N3) were up-regulated in the aged seeds $(\mathrm{A} 0 / \mathrm{CK})$, but no significant differences were observed for the NO treatment $(\mathrm{A} 1 / \mathrm{A} 0)$. The other two subunits (A0A200QHI3 and V4LNR7) were down-regulated with the NO treatment (A1/A0 and A1/CK). Plant mitochondria have two different pathways of electron transport: the cyanide-sensitive cytochrome pathway and the cyanide-resistant alternative pathway. With the administration of NO, the cytochrome pathway was inhibited and the alternative pathway might have changed. It has been reported that NO inhibited the cytochrome pathway, while the alternative pathway was not affected for soybean mitochondria [23].

Succinate dehydrogenase plays a central role in mitochondrion for linking the TCA cycle and ETC by catalyzing the succinate to fumarate. In our proteome analysis results, the subunit of Succinate-CoA ligase [ADP-forming] (I1LYN0 and K3ZV34) in aged seeds was significantly lower compared to CK. Succinate-CoA ligase can catalyze a reversible reaction, transforming succinyl-CoA 
and ADP or GDP to succinate and ATP or GTP [33]. Supplying $0.05 \mathrm{mM}$ of NO (A1) significantly increased the Succinate-CoA ligase [ADP-forming] subunit (I1LYN0 and K3ZV34) in aged seeds. This protein is involved in the subpathway that synthesizes succinate from succinyl-CoA. Subsequently, succinate dehydrogenase catalyzes succinate to fumarate [30]. Then, the fumarase (fumarate hydratase; E.C. 4.2.1.20) catalyzes the reversible hydration of fumarate to malate, which is a part of TCA. The results showed that the protein abundance of fumarate hydratase (Q10LR5) in the A1 treatment was significantly higher than that of the aged seeds (A0). Meanwhile, NAD-MDH activity also increased dramatically with the supplying of $0.05 \mathrm{mM}$ NO in aged seeds. MDH can catalyze the interconversion of malate and oxaloacetate, combined with the reduction or oxidation of the NAD pool [33]. NAD-MDH catalyzes NADH to reduce oxaloacetic acid and produce malate. The increase in fumarate hydratase and NAD-MDH suggested that there was an accumulation of malate. Malate can be oxidized by malic enzymes to yield pyruvate and $\mathrm{CO}_{2}$ through oxidative decarboxylation [34]. The mitochondrial pyruvate carrier (W5BQ98) protein was observably expressed in aged seeds with application of $0.05 \mathrm{mM} N O$ (A1). It has been reported that pyruvate acts on AOX to stimulate its activity in mitochondria isolated from the roots of soybean seedlings [35]. Pyruvate could activate AOX in the mitochondria of soybean cotyledons [36] and tobacco leaf [37]. It has been shown that external administration of pyruvate to isolated mitochondria results in activation of AOX pathways in wild type and pyruvate kinase transgenic lines, and transgenic lines decrease pyruvate [38]. The results demonstrated that the AOX pathway was enhanced following the NO treatment.

In general, the cytochrome pathway and alternative pathway branches point to ubiquinone. Exogenous NO inhibits the cyanide-sensitive cytochrome pathway and induces the cyanide-resistant alternative pathway. This suggests complex III is a major site of ROS production in the mitochondrial electron transport chain [39]. Alternative pathways did not pass through complex III, which could decrease the production of ROS in aged seeds with the exogenous NO. On the other hand, there was evidence that AOX played a particularly important role in regulating the balance of ROS. The AOX pathway could decrease the accumulation of ROS [14,40], and there was a higher accumulation of ROS when AOX was suppressed [15]. NO could reduce the production of ROS by inhibiting the cytochrome pathway and inducing the alternative pathway, and the alternative pathway was activated by pyruvate. It has been showed that the presence of exogenous NO induces AOX [11,41]. This was consistent with our results, where NO activated AOX pathways and thus reduced the generation of ROS.

Based on the results obtained in this study, we proposed a possible schematic pathway which might be operating during artificial aging (Figure 7). During oat seed aging, the expression of some proteins related to the TCA cycle were down-regulated and several enzymes related to mitochondrial ETC were up-regulated. Additionally, $\mathrm{H}_{2} \mathrm{O}_{2}$ of ROS accumulated dramatically, and some enzymes, including CAT, GR, MDHAR, and DHAR maintained the lower level in the AsA-GSH scavenging system. Finally, seed germination and seedling growth were limited as oat seeds aged. This indicated that seed aging led to a decrease in the activities of GR, DHAR, and MDHAR, accompanied by a gradual reduction in the mitochondrial inner membrane [2]. Changes in mitochondrial structure are posited to be responsible for the decrease in antioxidant enzymes in aged seeds, however this is worth further study. In view of the results for NO treatment in aged seeds, some enzyme activities located in the TCA cycle (such as succinate-CoA ligase and fumarate hydratase) and AsA-GSH (such as CAT, GR, MDHAR, and DHAR) were enhanced and $\mathrm{H}_{2} \mathrm{O}_{2}$ content declined at lower level, before alternative pathways were activated as the cytochrome pathway was inhibited. Seedling growth of aged oat seeds could regain normality and seed germinability could be retained to a certain level. Taken together, our results clearly demonstrate that exogenous $\mathrm{NO}$ in aged oat seeds can enhance seed vigor by improving enzyme activities in the AsA-GSH and decreasing the accumulation of $\mathrm{H}_{2} \mathrm{O}_{2}$. Furthermore, the enhancement of the TCA cycle and activated alternative pathway are beneficial for seedling growth in aged oat seeds with the application of $0.05 \mathrm{mM}$ NO. 


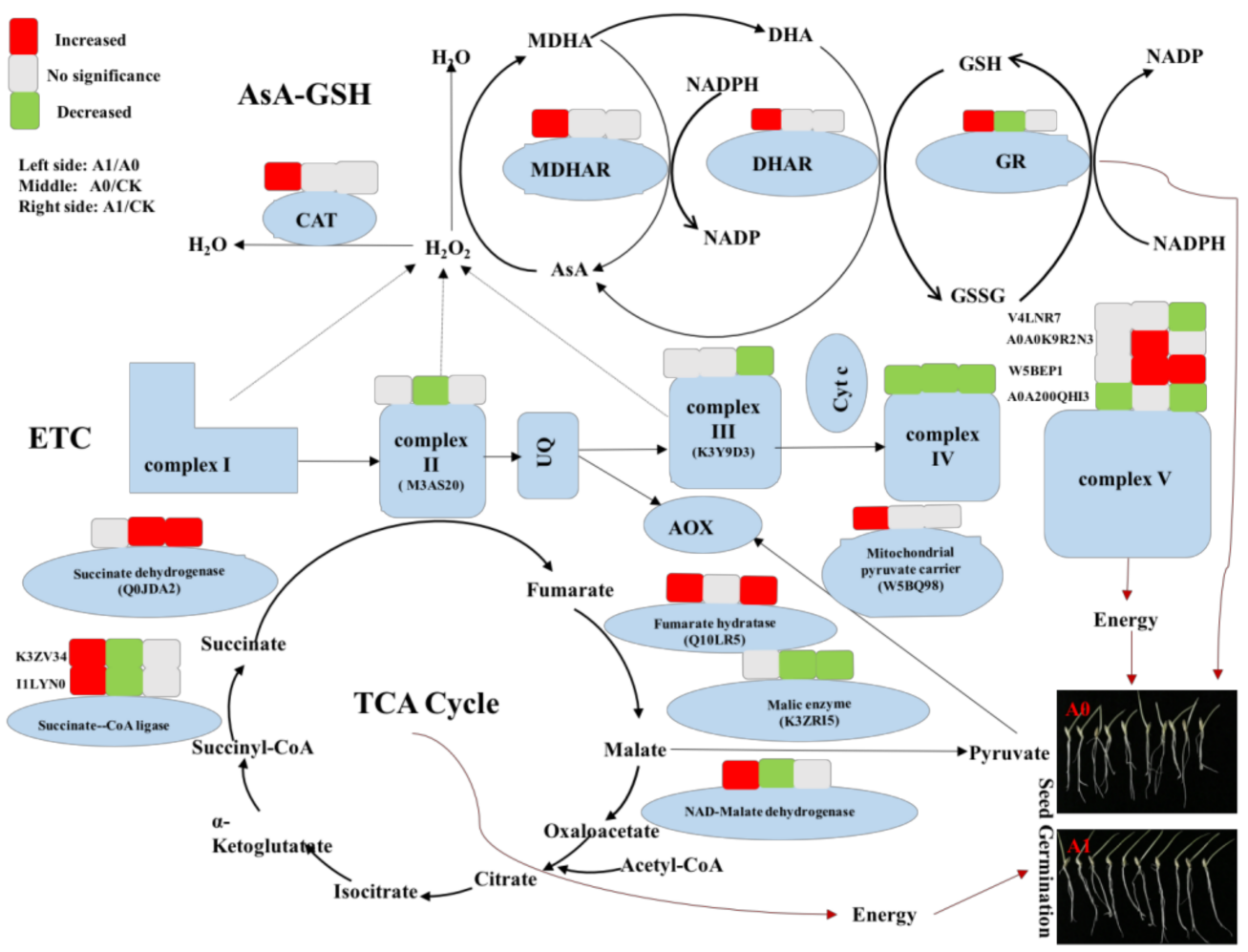

Figure 7. Schematic representation of protein abundance, ROS scavenging, and major biological pathways related to mitochondrial energy synthetic metabolism under NO treatment in aged oat seeds (different groups $\mathrm{A} 1 / \mathrm{A} 0, \mathrm{~A} 0 / \mathrm{CK}$, and $\mathrm{A} 1 / \mathrm{CK})$.

\section{Materials and Methods}

\subsection{Seed Materials}

Oat seeds (variety: Haywire) were bought from Beijing Clover Seed \& Turf Co. Ltd. (Beijing, China). The germination percentage of the seeds was $99 \%$ and original moisture content was $9.2 \%$.

\subsection{Determination of Seed Moisture Content}

The seed moisture content was determined in accordance with ISTA (2015) [42]. Approximately $4.5 \mathrm{~g}$ of seeds were placed in a sample container and weighed, and then they were oven-dried at $130 \sim 133^{\circ} \mathrm{C}$ for $2 \mathrm{~h}$ (two replicates). After cooling for $30 \mathrm{~min}$ in a desiccator, the seeds were weighed again and the moisture content was calculated.

\subsection{Adjusting the Seed Moisture Content}

The moisture content of seed samples was regulated to $10 \%$. Approximately $160 \mathrm{~g}$ of seeds were placed in a desiccator with saturated potassium chloride solution and weighed continually. When the seed weight was required to reach the corresponding moisture content, they were immediately placed into an aluminum foil bag and sealed, then incubated at $4{ }^{\circ} \mathrm{C}$ for 1 day, at least.

\subsection{Seed Aging Treatments}

After regulation of seed moisture content, the seeds in the aluminum foil bags were aged in a constant temperature water bath at $45^{\circ} \mathrm{C}$, and then aged 26 days seeds were used for experimental samples. The aged seed germination percentage was $68 \%$. 


\subsection{NO Treatment and Germination Test}

Uniform sized seeds were used in all treatments. The aged seeds were treated with 0 (A0), 0.05 (A1), 0.1 (A2), 0.5 (A3), and 1.0 (A4) $\mathrm{mM}$ sodium nitroprusside (SNP) for $8 \mathrm{~h}$ in the germination incubator (GXZ-380B, Ningbo, China), and the non-aged seeds (CK) were treated with distilled water for $8 \mathrm{~h}$ in the germination incubator (GXZ-380B, Ningbo, China). Then, all treatments were rinsed three times with distilled water. The SNP acted as a donor of NO. The seed samples after NO treatment were used in the germination trials. Germination was assayed according to the rules of ISTA (2015) [42]. Four replicates of 100 seeds were germinated in Petri dishes on filter paper with distilled water. The test was conducted in the germination incubator (GXZ-380B, Ningbo, China) at $20^{\circ} \mathrm{C}$ with $8 \mathrm{~h}$ light and $16 \mathrm{~h}$ dark for 10 days. On the 5th day, the length of the root and shoot were measured, and on the 10th day the number of normal seedlings was counted. When radicles emerged from the seed coat, the whole embryo and radicle were taken as subsequent experimental materials.

Mean germination time (MGT) was calculated according to Ellis and Roberts [43]. Mean germination time (days) $=\Sigma(\mathrm{nd}) / \Sigma \mathrm{n}$, where $\mathrm{n}$ was number of germinated seeds $(2 \mathrm{~mm}$ radicle growth through seed coat) in day, $\mathrm{d}$, of counting seed germination, and $\Sigma \mathrm{n}$ was total germinated seeds.

\subsection{Isolation and Purification of Mitochondria}

Mitochondria were extracted with 80 embryos collected from seeds with radicles protruding $5 \mathrm{~mm}$ after imbibition for $66 \mathrm{~h}$ (aged seeds) and $42 \mathrm{~h}$ (non-aged seeds). All extraction procedures were carried out at $0 \sim 4{ }^{\circ} \mathrm{C}$. The embryos were ground with a mortar and pestle, using a grinding medium. The grinding medium was composed of $50 \mathrm{mM}$ phosphate buffer ( $\mathrm{pH} 7.5$ ), $0.3 \mathrm{M}$ mannitol, $0.5 \%(w / v)$ bovine serum albumin (BSA), $0.5 \%(w / v)$ polyvinylpyrrolidone- $40,0.2 \mathrm{mM}$ EDTA-2Na, and $20 \mathrm{mM}$ cysteine. The homogenate was centrifuged at $2000 \times \mathrm{g}$ for $10 \mathrm{~min}$ approximately twice. The supernatant was centrifuged at $12,000 \times g$ for $15 \mathrm{~min}$. The precipitate was suspended in a wash medium buffer containing $0.3 \mathrm{M}$ mannitol, $0.1 \%(w / v) \mathrm{BSA}$, and $10 \mathrm{mM} \mathrm{N}$-[Tris (hydroxymethyl) metyl]-2-aminopropanesulfonic acid (TES) ( $\mathrm{pH} 7.5$ ), and centrifuged again at 12,000 $\times \mathrm{g}$ for $15 \mathrm{~min}$. The final precipitate was washed once with a wash medium and suspended in a small volume of the medium (mitochondrial fraction). The crude mitochondria extract was used for enzyme activity determination.

For pure mitochondria, the suspension was loaded onto a Percoll step gradient consisting of 1:4:2 ratios, bottom to top, of $40 \%$ Percoll: $21 \%$ Percoll: $16 \%$ in a mannitol wash buffer. The mixture was centrifuged for $1 \mathrm{~h}$ at $40,000 \times g$, and the mitochondria presented as an opaque band at the $21 / 40 \%$ and $16 / 21 \%$ interface. The mitochondrial band was collected and washed three times by centrifugation at $20,000 \times g$ for $15 \mathrm{~min}$ in a wash buffer containing $0.3 \mathrm{M}$ mannitol, $0.1 \%(w / v) \mathrm{BSA}$, and $10 \mathrm{mM}$ TES (pH 7.5), and the last time without BSA in the wash buffer.

\subsection{Determination of $\mathrm{H}_{2} \mathrm{O}_{2}$ Content}

The $\mathrm{H}_{2} \mathrm{O}_{2}$ content in the mitochondria of the embryo was carried out using a commercial chemical assay kit (Nanjing Jianchen Bioengineering Institute, Nanjing, China) according to the manufacturer's instruction.

\subsection{Enzyme Assays}

Determination of the protein content in the mitochondria of the embryo was carried out using a commercial chemical assay kit (Suzhou Comin Biotechnology Institute, Suzhou, China) according to the manufacturer's instruction. The assay was based on the Coomassie brilliant blue G-250 bound to protein to form a blue complex in the acidic solution, which shows a maximum absorption peak at $595 \mathrm{~nm}$.

Catalase (CAT) (EC 1.11.1.6) activity in the mitochondria of the embryo was measured by the dynamic change in absorbance at $240 \mathrm{~nm}$ after $1 \mathrm{~min}$, due to the decline of extinction of $\mathrm{H}_{2} \mathrm{O}_{2}$. A total 
of $20 \mu \mathrm{L}$ of the supernatant was mixed with $800 \mu \mathrm{L}$ phosphate buffer $(25 \mathrm{mM}, \mathrm{pH}$ 7.0, mixed with $0.1 \mathrm{mM}$ EDTA) and $200 \mu \mathrm{L} 100 \mathrm{mM} \mathrm{H}_{2} \mathrm{O}_{2}$.

GR (EC 1.6.4.2) in the mitochondria of the embryo was carried out using a commercial chemical assay kit (Suzhou Comin Biotechnology Institute, Suzhou, China) according to the manufacturer's instruction. One GR activity unit was defined as the decreasing rate of absorbance of $1 \mathrm{nmol}$ NADPH per min at $340 \mathrm{~nm}$.

DHAR (EC 1.8.5.1) in the mitochondria of the embryo was carried out using a commercial chemical assay kit (Suzhou Comin Biotechnology Institute, Suzhou, China) according to the manufacturer's instruction. One DHAR activity unit was defined as the increase in absorbance of $1 \mathrm{nmol}$ AsA per min at $265 \mathrm{~nm}$.

MDHAR (EC1.6.5.4) in the mitochondria of the embryo was carried out using a commercial chemical assay kit (Suzhou Comin Biotechnology Institute, Suzhou, China) according to the manufacturer's instruction. One MDHAR activity unit was defined as the oxidation of $1 \mathrm{nmol}$ NADPH per min at $340 \mathrm{~nm}$.

Complex IV in the mitochondria of the embryo was carried out using a commercial chemical assay kit (Suzhou Comin Biotechnology Institute, Suzhou, China) according to the manufacturer's instruction. A complex IV activity unit was defined as the catalytic degradation of $1 \mathrm{nmol}$ of reductive cytochrome c per min at $550 \mathrm{~nm}$.

NAD-MDH in the mitochondria of the embryo was carried out using a commercial chemical assay kit (Suzhou Comin Biotechnology Institute, Suzhou, China) according to the manufacturer's instruction. One NAD-MDH activity unit was defined as the consumption of $1 \mathrm{nmol} \mathrm{NADH}$ per min at $340 \mathrm{~nm}$.

\subsection{Protein Quantification and Digestion}

Pure mitochondrial protein concentration was measured using the Bradford method. The appropriate amount of protein sample was mixed with $8 \mathrm{M}$ urea solution to be quantified. According to the quantitative results above, the protein sample (500 $\mu$ g each sample) was reduced by $10 \mathrm{mM}$ DTT at $37^{\circ} \mathrm{C}$ for $2.5 \mathrm{~h}$ and IAA was added to the final concentration of $10 \mathrm{mM}$ at room temperature for $40^{\circ} \mathrm{C}$ min in darkness. All samples were transferred in the filter of a centrifuge tube (MW cutoff was $10 \mathrm{kDa}$ ). After reduction with DTT and alkylation with iodoacetamide, the proteins on the filter were washed three times using a lysis buffer and $\mathrm{ABC}$ solution $(0.05 \mathrm{M} \mathrm{NH} 4 \mathrm{HCO} 3$ in water), respectively. Then, the samples were digested by trypsin ( $1 \mu \mathrm{g}$ trypsin for $100 \mu \mathrm{g}$ protein $)$ and incubated at $37^{\circ} \mathrm{C}$ for $16 \mathrm{~h}$. Subsequently, the peptide samples were used for LC-MS/MS analysis.

\subsection{Mass Spectrometry Method and Data Analysis}

\subsubsection{DDA Sample Acquisition}

In order to generate the spectral library, peptides from each sample were mixed and acquired twice with a data dependent acquisition (DDA) mode using Q Exactive HF (Bremen, Germany, Thermo Fisher). The peptide mixture was separated using an EasyNano LC1000 system (San Jose, Thermo Fisher) with a home-made C18 column $(3 \mu \mathrm{m}, 75 \mu \mathrm{m} \times 15 \mathrm{~cm})$ at a flow rate of $450 \mathrm{~nL} / \mathrm{min}$. A 120-min linear gradient was set as follows: $3 \% \mathrm{~B}\left(0.1 \% \mathrm{FA}\right.$ in $\left.\mathrm{H}_{2} \mathrm{O}\right) / 97 \% \mathrm{~A}\left(0.1 \% \mathrm{FA}\right.$ in $\left.\mathrm{H}_{2} \mathrm{O}\right)$ to $6 \% \mathrm{~B}$ in $12 \mathrm{~min}$; $6 \% \mathrm{~B}$ to $22 \% \mathrm{~B}$ in $75 \mathrm{~min} ; 22 \% \mathrm{~B}$ to $35 \% \mathrm{~B}$ in $20 \mathrm{~min} ; 35 \% \mathrm{~B}$ to $100 \% \mathrm{~B}$ in $6 \mathrm{~min}$; and $7 \mathrm{~min}$ for $100 \% \mathrm{~B}$. For the data acquisition, a top 20 scan mode with MS1 scan range $m / z$ 400-1200 was used, and other parameters were set as below: MS1 and MS2 resolution was set to $120 \mathrm{~K}$ and $30 \mathrm{~K}$; AGC for MS1 and MS2 was $3 \times 10^{6}$ and $1 \times 10^{6}$; isolation window was $2.0 \mathrm{Th}$; NCE was 27 ; and dynamic exclusion time was $20 \mathrm{~s}$. 


\subsubsection{Spectral Library Generation}

DDA raw files were searched against a Uniprot protein database containing all plant proteins (downloaded on 2017.10.12, 2,304,711 entries) using Proteome Discoverer 2.1 (San Jose). The protein sequence was appended with the iRT fusion protein sequence (Biognosys, Schlieren, Switzerland). A search engine of SequestHT was used with the following searching parameters: enzyme of trypsin with maximum number of two missed cleavages; precursor and fragment ion mass tolerance was set to $10 \mathrm{ppm}$ and $0.02 \mathrm{Da}$; variable modification was set to Oxidation of $\mathrm{M}$, deamination of $\mathrm{N}, \mathrm{Q}$, Acetylation of Protein $\mathrm{N}$ terminus and fixed modification was set to carbamidomethylation of $\mathrm{C}$; an algorithm of Percolator [44] was used to keep peptide FDR less than $1 \%$ and the q-value used for protein identification was 0.01 . The search results of data-dependent acquisition using Proteome Discoverer 2.1 was transferred into a spectral library using Spectronaut 10 (Biognosys). Only a high confidence of peptide was used for the generation of the spectral library. Fragment ions within the mass range of $m / z$ 300-1800 were kept and peptides less than three fragment ions were removed.

\subsubsection{DIA Sample Acquisition}

Each sample, with the addition of the same amount of iRT, was analyzed using a data independent acquisition (DIA) method. This method consisted of one full MS1 scan, with resolution set at $60 \mathrm{~K}$ using AGC of $3 \times 10^{6}$ and a maximum injection time of $20 \mathrm{~ms}$. Sequential 29 isolation mass windows were set as follows: for $m / z 400$ to 800 , the mass isolation window was set to $20 \mathrm{Th}$; for $m / z$ 800-1000, the mass isolation window was set to $40 \mathrm{Th}$; and for $m / z$ 1000-1200, the mass isolation window was set to 50 Th. Each DIA MS2 spectrum was acquired using a resolution of $30 \mathrm{~K}$ and AGC was set to $1 \times 10^{6}$, maximum injection time was $45 \mathrm{~ms}$ and collision energy was set to NCE 30. All the LC conditions were exactly the same as the DDA sample acquisition listed above.

\subsubsection{DIA Data Analysis}

DIA raw data were processed using Spectronaut 10. Default settings were used for protein identification and quantitation. Peak detection, dynamic iRT, correction factor 1, interference correction, and cross run normalization, were enabled. All peptides were filtered using a $Q$ value $\leq 0.01$. The average quantity of fragment ion areas from the top three peptides were used to compare protein abundance between samples.

\subsubsection{Identification of Mitochondrial Proteins}

Mitochondrial protein analysis was conducted when the quantitative proteins were screened for mitochondrion markers. At the same time, all proteins were submitted to DAVID (https://david. ncifcrf.gov/) and to GO annotation. Mitochondrial proteins were enriched in the mitochondria related pathways by analyzing the Cellular Component. In the study, proteins with a fold change of $>1.2$ or $<0.8$ ( $p$-value $\leq 0.05$ ) were regarded as differentially expressed proteins. The functions of these differential proteins were used as Basic Local Alignment Search Tools (BLAST) to find regions of local similarity between sequences in The Arabidopsis Information Resource (TAIR). Then, MapMan (MapManlnst-3.5.1 R2) was used to classify the functions of those mitochondrial proteins.

\subsection{Statistical Analyses}

The mean of three or four replicates was analyzed using analysis of variance (ANOVA), which was performed using SPSS 23.0 software. Duncan's multiple range test was used to compare the treatment means of germination, physiological indicators and enzyme activities. Data was presented as means \pm SD from three or four replications for each treatment. Different letters indicated significant differences among NO treatments $(p<0.05)$. 
Acknowledgments: This research was financially supported by funding from the National Natural Science Foundation (31572454), China Agriculture Research System (CARS-34), and Beijing Common Construction Project.

Author Contributions: Chunli Mao and Yanqiao Zhu designed and performed the experiments; Chunli Mao analyzed the data and wrote the manuscript; Peisheng Mao designed and supervised the research and edited the manuscript; and Huifang Yan, Hang Cheng, Liyuan Zhao, Jia Tang and Xiqing Ma were involved in performing the experiments.

Conflicts of Interest: The authors declare no conflict of interest.

\section{Abbreviations}

$\begin{array}{ll}\text { CAT } & \text { Catalase } \\ \text { DHAR } & \text { Dehydroascorbate reductase } \\ \text { ETC } & \text { Electron transport chain } \\ \text { GR } & \text { Glutathione reductase } \\ \mathrm{H}_{2} \mathrm{O}_{2} & \text { Hydrogen peroxide } \\ \mathrm{MGT} & \text { Mean germination time } \\ \text { MDHAR } & \text { Monodehydroascorbate reductase } \\ \text { NAD-MDH } & \text { NAD-malate dehydrogenase } \\ \text { TCA } & \text { Tricarboxylic acid }\end{array}$

\section{References}

1. EI-Maarouf-Bouteau, H.; Mazuy, C.; Corbineau, F.; Bailly, C. DNA alteration and programmed cell death during ageing of sunflower seed. J. Exp. Bot. 2011, 62, 5003-5011. [CrossRef] [PubMed]

2. Xia, F.S.; Wang, M.Y.; Li, M.L.; Mao, P.S. Mitochondrial structural and antioxidant system responses to aging in oat (Avena sativa L.) seeds with different moisture contents. Plant Physiol. Biochem. 2015, 94, 122-129. [CrossRef] [PubMed]

3. Yan, H.F.; Mao, P.S.; Sun, Y.; Li, M.L. Impacts of ascorbic acid on germination, antioxidant enzymes and ultrastructure of embryo cells of aged elymus sibiricus seeds with different moisture contents. Int. J. Agric. Biol. 2016, 18, 176-183. [CrossRef]

4. McDonald, M.B. Seed deterioration: Physiology, repair and assessment. Seed Sci. Technol. 1999, $27,177-237$.

5. Baily, C.; El-maarouf-bouteau, H.; Corbineau, F. From intracellular signaling networks to cell death: The dual of reactive oxygen species in seed physiology. CR Biol. 2008, 331, 806-814. [CrossRef] [PubMed]

6. Kibinza, S.; Vinel, D.; Côme, D.; Bailly, C.; Corbineau, F. Sunflower seed deterioration as related to moisture content during aging, energy metabolism and active oxygen species scavenging. Physiol. Plant. 2006, 128, 496-506. [CrossRef]

7. Li, Y.; Wang, Y.; Xue, H.; Pritchard, H.W.; Wang, X.F. Changes in the mitochondrial protein profile due to ROS eruption during ageing of elm (ulmus pumila L.) seeds. Plant Physiol. Biochem. 2017, 114, 72-87. [CrossRef] [PubMed]

8. Møller, I.M. Plant mitochondria and oxidative stress: Electron transport, NADPH turnover, and metabolism of reactive oxygen species. Annu. Rev. Plant Physiol. Plant Mol. Biol. 2001, 52, 561-591. [CrossRef] [PubMed]

9. Fleury, C.; Mignotte, B.; Vayssière, J.L. Mitochondrial reactive oxygen species in cell death signaling. Biochimie 2002, 84, 131-141. [CrossRef]

10. Rhoads, D.M.; Umbach, A.L.; Subbaiah, C.C.; Siedow, J.N. Mitochondrial reactive oxygen species, contribution to oxidative stress and interorganellar signaling. Plant Physiol. 2006, 141, 357-366. [CrossRef] [PubMed]

11. Vanlerberghe, G.C. Alternative oxidase: A mitochondrial respiratory pathway to maintain metabolic and signaling homeostasis during abiotic and biotic stress in plants. Int. J. Mol. Sci. 2013, 14, 6805-6847. [CrossRef] [PubMed]

12. Navrot, N.; Rouhier, N.; Gelhaye, E.; Jacquot, J.P. Reactive pxygen species generation and antioxidant systems in plant mitochondria. Physiol. Plant. 2007, 129, 185-195. [CrossRef]

13. Affourtit, C.; Krab, K.; Moore, A.L. Control of plant mitochondrial respiration. Biochim. Biophys. Acta 2001, 1504, 58-69. [CrossRef] 
14. Wu, Q.; Feng, H.Q.; Li, H.Y.; Wang, D.S.; Liang, H.G. Effects of drought stress on cyanide-resistance respiration and metabolism of reactive oxygen in wheat seedling. J. Plant Physiol. Mol. Biol. 2006, 32, 217-224.

15. Fiorani, F.; Umbach, A.L.; Siedow, J.N. The alternative oxidase of plant mitochondria is involved in the acclimation of shoot growth at low temperature. A study of Arabidopsis AOX1a transgenic plants. Plant Physiol. 2005, 139, 1790-1805. [CrossRef] [PubMed]

16. Bailly, C. Active oxygen species and antioxidants in seed biology. Seed Sci. Res. 2004, 14, 93-107. [CrossRef]

17. Xin, X.; Tian, Q.; Yin, G.K.; Chen, X.L.; Zhang, J.M.; Sophia, N.G.; Lu, X.X. Reduced mitochondrial and ascorbate-glutathione activity after artificial ageing in soybean seed. J. Plant Physiol. 2014, 177, 140-147. [CrossRef] [PubMed]

18. Das, K.; Roychoudhury, A. Reactive oxygen species (ROS) and response of antioxidants as ROS-scavengers during environment stress in plants. Front. Environ. Sci. 2014, 2, 1-13. [CrossRef]

19. Krasuska, U.; Gniazdowska, A. Nitric oxide and hydrogen cyanide as regulating factors of enzymatic antioxidant system in germination apple embryos. Acta Physiol. Plant. 2012, 34, 683-692. [CrossRef]

20. Zheng, C.F.; Jiang, D.; Liu, F.L.; Dai, T.B.; Liu, W.C.; Jing, Q.; Cao, W.X. Exogenous nitric oxide improves seed germination in wheat against mitochondrial oxidative damage induced by high salinity. Environ. Exp. Bot. 2009, 67, 222-227. [CrossRef]

21. Lin, Y.; Liu, Z.Z.; Shi, Q.; Wei, M.; Yang, F.J. Exogenous nitric oxide (NO) increased antioxidant capativity of cucumber hypocotyl and radicle under salt stress. Sci. Hortic. 2012, 142, 118-127. [CrossRef]

22. Hu, K.D.; Hu, L.Y.; Li, Y.H.; Zhang, F.Q.; Zhang, H. Protective roles of nitric oxide on germination and antioxidant metabolism in wheat seeds under copper stress. Plant Growth Regul. 2007, 53, 173-183. [CrossRef]

23. Millar, A.H.; Day, D.A. Nitric oxide inhibits the cytochrome oxidase but not the alternative oxidase of plant mitochondria. FEBS Lett. 1996, 398, 155-158. [CrossRef]

24. Royo, B.; Moran, J.F.; Ratcliffe, R.G.; Gupta, K.J. Nitric oxide induces the alternative oxidase pathway in Arabidopsis seedlings deprived of inorganic phosphate. J. Exp. Bot. 2015, 60, 6273-6280. [CrossRef] [PubMed]

25. Yin, G.K.; Whelan, J.; Wu, S.H.; Zhou, J.; Chen, B.; Chen, X.L.; Zhang, J.M.; He, J.J.; Xin, X.; Lu, X.X. Comprehensive mitochondrial metabolic shift during the critical node of seed ageing in rice. PLoS ONE 2016, 11, 1-19. [CrossRef] [PubMed]

26. Xin, X.; Lin, X.H.; Zhou, Y.C.; Chen, X.L.; Liu, X.; Lu, X.X. Proteome analysis of maize seeds: The effect of artificial ageing. Physiol. Plant. 2011, 143, 126-138. [CrossRef] [PubMed]

27. Belibni, M.V.; Lamattina, L. Nitric oxide stimulates seed germination and de-etiolation and inhibits hypocotyl elongation, three light-inducible responses in plants. Planta 2000, 210, 215-221. [CrossRef] [PubMed]

28. Mattews, S.; Noli, E.; Demir, I.; Khajeh-Hosseini, M.; Wagner, M.H. Evaluation of seed quality: From physiology to international standardization. Seed Sci. Res. 2012, 22, S69-S73. [CrossRef]

29. Law, S.R.; Narsai, R.; Whelan, J. Mitochondrial biogenesis in plants during seed germination. Mitochondrion 2014, 19, 214-221. [CrossRef] [PubMed]

30. Jardim-messeder, D.; Caverzan, A.; Rauber, R.; Ferreira, E.S.; Margis-Pinheiro, M.; Galina, A. Succinate dehydrogenase (mitochondrial complex II) is a source of reactive oxygen species in plants and regulates sevelopment and stress responnses. New Phytol. 2015, 208, 776-789. [CrossRef] [PubMed]

31. Brown, G.C. Nitric oxide regulates mitochondrial respiration and cell function by inhibiting cytochrome oxidase. FEBS Lett. 1995, 369, 136-139. [CrossRef]

32. Brown, G.C. Regulation of mitochondrial respiration by nitric oxide inhibition of cytochrome c oxidase. Biochim. Biophys. Acta 2001, 1504, 46-57. [CrossRef]

33. Johnson, J.D.; Mehus, J.G.; Tews, K.; Milavetz, B.L.; Lambeth, D.O. Genetic evidence for the expression of ATPand GTP-specific Succinyl-CoA synthetases in multicellular eucaryotes. J. Biochem. 1998, 273, 27580-27586. [CrossRef]

34. Maurino, V.G.; Gerrard Wheeler, M.C.; Andreo, C.S.; Drincovich, M.F. Redoundancy is sometimes seen only by the uncritical: Does Arabidopsis need six malic enzyme isoform. Plant Sci. 2009, 176, 715-721. [CrossRef]

35. Millar, A.H.; Wiskich, J.T.; Whelan, J.; Day, D.A. Organic acid activation of the alternative oxidase of plant mitochondria. FEBS Lett. 1993, 329, 259-262. [CrossRef]

36. Day, A.A.; Millar, A.H.; Wiskich, J.T.; Whelan, J. Regulation of alternative oxidase by pyruvate in soybean mitochondria. Plant Physiol. 1994, 106, 1421-1427. [CrossRef] [PubMed] 
37. Vanlerberghe, G.C.; Day, D.A.; Wiskich, J.T.; Vanlerberghe, A.E.; Mclntosh, L. Alternative oxidase activity in tobacco leaf mitochondria (Dependence on trucarboxylic acid cycle-mediated redox regulation and pyruvate activation). Plant Physiol. 1995, 109, 353-361. [CrossRef] [PubMed]

38. Oliver, S.N.; Lunn, J.E.; Urbanzcyk-Wochniak, E.; Lytovchenko, A.; Van Dongen, J.T.; Faix, B.; Schmalzlin, E.; Fernie, A.R.; Geigenberger, P. Decreased expression of cytosolic pyruvate kinase in potato tubers lead to a decline in pyruvate resulting in an in vivo repression of the alternative oxidase. Plant Physiol. 2008, 148, 1640-1654. [CrossRef] [PubMed]

39. Raha, S.; Robinson, B.H. Mitochondria, oxygen free radicals, disease and ageing. Trends Biochem. Sci. 2000, 25, 502-508. [CrossRef]

40. Maxwell, D.P.; Wang, Y.; Mclotosh, L. The alternative oxidase lowers mitochondrial reactive oxygen production in plant cells. Proc. Natl. Acad. Sci. USA 1999, 96, 8271-8276. [CrossRef] [PubMed]

41. Huang, X.; Rad, U.V.; Durner, J. Nitric oxide induces transcriptional activation of the nitric oxide-tolerant alternative oxidase in Arabidopsis suspension cells. Planta 2002, 215, 914-923. [CrossRef] [PubMed]

42. ISTA. International Rules for Seed Testing; International Seed Testing Association: Basserdorf, Awitzerland, 2015.

43. Ellis, R.A.; Roberts, E.H. The quantification of ageing and survival in orthodox seeds. Seed Sci. Res. 1981, 9, 373-409.

44. Spivak, M.; Weston, J.; Bottou, L.; Kall, L.; Noble, W.S. Improvements to the percolator algorithm for peptide identification from shotgun proteomics data sets. J. Proteom. Res. 2009, 8, 3737-3745. [CrossRef] [PubMed]

(C) 2018 by the authors. Licensee MDPI, Basel, Switzerland. This article is an open access article distributed under the terms and conditions of the Creative Commons Attribution (CC BY) license (http://creativecommons.org/licenses/by/4.0/). 